\title{
The Adverse Effects of High-dose Corticosteroids with Early and Late Severe Morbidity in the Treatment of Patients with Multiple Sclerosis: Long-term Observation Results
}

\author{
Multipl Skleroz Hastalarının Atak Tedavisinde Yüksek Doz Kortikosteroid \\ Kullanımının Erken ve Geç Dönem Ağır Morbiditeye Yol Açan Yan Etkileri: Uzun \\ Dönem Gözlem Sonuçları
}

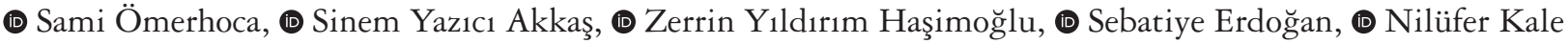
Bagcilar Training and Research Hospital, Clinic of Neurology, Istanbul, Turkey

\begin{abstract}
Objective: Intravenous methylprednisolone (IVMP) is the most commonly used emergency treatment for multiple sclerosis (MS) attacks and the risk of adverse effects is high due to frequent use. The aim of our study was to investigate the relationship between adverse effects that can lead to severe morbidity and possible pharmaceutic and/or physiologic causes.

Materials and Methods: This study included patients with clinically definite MS who underwent IVMP treatment between 2010-2018. The corticosteroid treatment dose and duration, demographic characteristics, laboratory findings and adverse effect profiles of the patients were examined.

Results: The medical records of 390 patients ( $/ \mathrm{M}=294 / 96)$ with follow-up were evaluated retrospectively. Eleven ( $\mathrm{F} / \mathrm{M}=8 / 3)$ patients who developed severe complications after IVMP were detected. The drug infusion was ceased in two patients due to severe allergic reactions or tachyarrhythmia. One patient with severe tachycardia and two patients with corticosteroid-induced allergy received IVMP therapy along with alternative treatment and observation methods. In nine patients, avascular bone necrosis (AVN) developed after the treatment. AVN was multifocal in six patients and monofocal in three patients. The most frequently affected localization was the femoral head (six patients), followed by the tibia and talus. Only one patient had a high and repeated-dose (42 $\mathrm{g}$ total) drug use. Two patients received single-dose IVMP treatment.

Conclusion: In our study, the treatment-related complications of patients diagnosed as having clinical definite MS and receiving IVMP were defined and it was thought that they might not be related to drug dose and duration.
\end{abstract}

Keywords: Avascular bone necrosis, corticosteroids, multiple sclerosis, adverse effect

$\ddot{O} z$

Amaç: İntravenöz metilprednizolon (IVMP) tedavisi multipl skleroz (MS) ataklarında en sık başvurulan acil tedavi şeklidir ve sık kullanımı nedeniyle yan etki görülme riski yüksektir. Çalışmamızın amacı ağır morbiditeye yol açabilecek yan etkilerin olası farmasötik ve/veya fizyolojik sebeplerle ilişkisini incelemektir.

Gereç ve Yöntem: Bu çalışmaya 2010-2018 tarihleri arasında klinik kesin MS (KKMS) tanısı ile takip edilen ve IVMP tedavisi alan hastalar dahil edildi. Hastaların kortikosteroid (KS) tedavi doz ve süreleri, demografik özellikleri, laboratuvar bulguları ve yan etki profilleri incelendi.

Bulgular: Takipleri sürdürülen $390(\mathrm{~K} / \mathrm{E}=294 / 96)$ hastanın dosyası retrospektif olarak incelendi. IVMP sonrası ağır komplikasyon gelişen $11(\mathrm{~K} / \mathrm{E}=8 / 3)$ hasta saptandı. İki hastada şiddetli alerjik reaksiyonlar veya taşiaritmiler nedeniyle ilaç infüzyonu durdurulmak zorunda kalındı. Bir hasta şiddetli taşikardi ve 2 hasta KS ajanlara bağlı alerji nedeniyle IVMP tedavisini alternatif tedavi ve gözlem yöntemlerinin eşliğinde alabildiler. Hastalardan 9'unda tedavi sonrasında avasküler kemik nekrozu (AVN) geliştiği, bu hastaların 6'sında AVN'nin multifokal, üçünde ise monofokal geliştiği görüldü. En sık etkilenen lokalizasyon femur başıydı (9 hastanın 6's1), bunu tibia ve talus takip etmekteydi. Sadece 1 hastada yüksek ve tekrar dozda (toplam $42 \mathrm{gr}$ ) ilaç kullanımı vardı. İki hasta bir kez IVMP tedavisi almişt1.

Sonuç: Çalışmamızda KKMS tanılı ve IVMP alan hastaların tedavi nedeniyle gelişen komplikasyonları tanımlandı ve bunların ilaç dozu ve süresi ile ilişkili olmayabileceği düşünüldü.

Anahtar Kelimeler: Avasküler kemik nekrozu, kortikosteroidler, multipl skleroz, yan etki

Address for Correspondence/Yazışma Adresi: Sami Ömerhoca MD, Bagcilar Training and Research Hospital, Clinic of Neurology, Istanbul, Turkey Phone: +90 5448647809 E-mail: samiyumerhodzha@yahoo.com ORCID ID: orcid.org/0000-0002-5899-1180

Received/Geliş Tarihi: 08.07.2018 Accepted/Kabul Tarihi: 13.01.2019

${ }^{\circ}$ Copyright 2019 by Turkish Neurological Society

Turkish Journal of Neurology published by Galenos Publishing House. 


\section{Introduction}

Multiple sclerosis (MS) is an autoimmune demyelinating disease with relapses and remissions (1). The condition that we evaluate as an attack is the emergence of new findings related to the inflammatory and demyelinating process or the increase in the existing findings and persistence for at least 24 hours (2). Corticosteroids (CS) are the most commonly used treatment for acute attacks. As a general recommendation, intravenous methylprednisolone (IVMP) is administered at a dosage of 1000 $\mathrm{mg} /$ day for 3 to 10 days, followed by decreasing and discontinuing oral methylprednisolone in some centers $(3,4)$. CS are widely used because of their easy application and the adverse effect profile is also quite wide. These include skin, hematopoietic system, endocrine system, musculoskeletal system, behavioral changes, and gastrointestinal symptoms. Among these, especially in the case of severe iatrogenic adverse effects on bone structure, osteoblast activity is suppressed and the reabsorption of calcium from the intestines and kidneys decreases and the tendency for osteoporosis increases (5). The most common cause of non-traumatic bone fractures is avascular bone necrosis (AVN); the terms ischemic necrosis, osteochondritis dissecans, subchondral avascular necrosis are also used (6). The most commonly accepted pathogenetic mechanisms are micro embolization, bone marrow edema, and vascular wall damage, and the disease most commonly involves the hip joint and femoral head (Appendix 1) $(6,7)$.

In this study, the acute and long-term adverse effect profiles of CS in patients with clinically definite MS (CDMS) who received IVMP for the treatment of attacks during the disease course were evaluated, and the treatment approaches were discussed.

\section{Materials and Methods}

Patients who were followed up in the MS unit of our clinic with a diagnosis of CDMS between 2010 and 2018 were evaluated retrospectively (8). Patients who were treated with IVMP during the disease course, who developed acute or chronic adverse effects associated with the treatment, and who had sufficient data in the patient files were included in the study. Patients with other medical conditions (trauma, chronic alcoholism, pregnancy, oral contraceptive use, Caisson disease, smoking, radiation exposure and coagulation diseases) (6) with a tendency to osteoporosis or AVN were excluded. The patients were grouped according to their time of first symptom presentation: symptoms in the first 4 weeks were considered as acute, and symptoms after 4 weeks were considered as chronic. Adverse effects, total CS dose, the duration of CS treatment, the number of attacks requiring CS during this follow-up period, and the disease-modifying additional therapies used during this period were evaluated.

Informed consent was obtained from all subjects included in our study and study were approved by the Bagcilar Training and Research Hospital of Clinical Research Ethics Committee (protocol number: 2018.05.1.04.047, date: 11.05.2018).

\section{Statistical Analysis}

In addition to descriptive statistical methods (mean, standard deviation), power analysis of the groups was performed, and oneway analyis of variance (ANOVA) and Student's t-test were used for the comparison of normally distributed quantitative data. The Kruskal-Wallis test and Mann-Whitney U test were used to compare parameters that did not show normal distribution. The chi-square test and Fisher's exact test were used to compare qualitative data. $\mathrm{P}<0.05$ was considered statistically significant. SPSS version 10.0 was used for statistical analysis.

\section{Results}

The data of 390 patients with CDMS, 294 females (75\%) and 96 males (25\%), who were followed up in the clinic were examined. Among those, 11 (2.8\%) patients with acute or chronic adverse effects after IVMP were included in the study. Eight $(72 \%)$ were female and $3(28 \%)$ were male. The mean age was

Table 1. Demographic and treatment data of patients with observed adverse effects and avascular bone necrosis after corticosteroid treatment

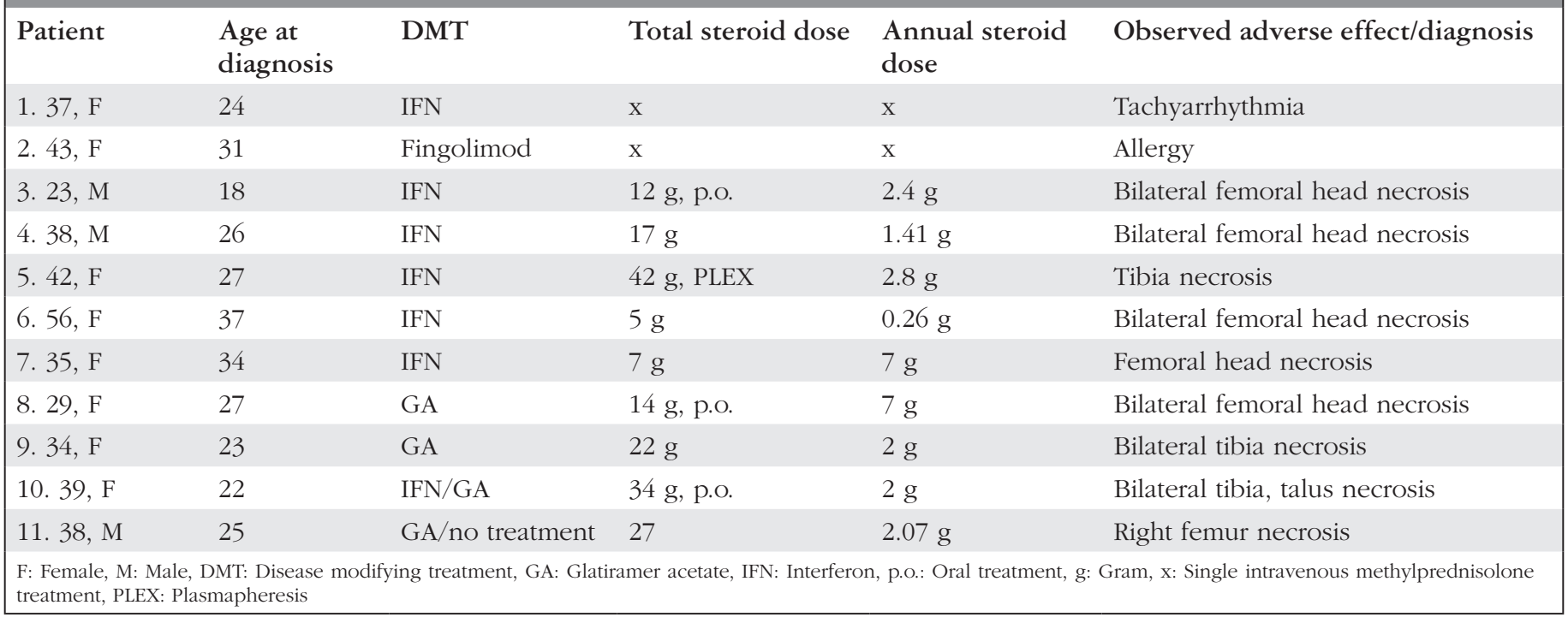


26.7 \pm 5.4 (minimum-maximum: 23-56) years (Table 1). The treatment was ceased in one patient due to severe tachyarrhythmia during and immediately after treatment, and in one patient due to hypersensitive macular skin lesions and allergy.

In line with the criteria determined in our study, two patients with tachyarrhythmia and allergy were considered as patients with early adverse events. A 37-year-old female patient with tachyarrhythmia (Table 1: Patient 1) could receive IVMP for treatment-requiring attacks only with monitoring and close clinical follow-up. The other patient (Table 1: Patient 2), who was a 43-yearold woman, had diffuse and rapidly developing hypersensitive skin reactions during the first IVMP administration, and these could not be suppressed with routine anti-allergic agents. Therefore, the patient, who was on disease-modifying therapy (DMT), needed to use adrenocorticotropic hormone (ACTH) during the attacks.

The remaining 9 patients, 6 females $(67 \%)$ and 3 males $(33 \%)$, had AVN. The mean age of the patients was 26.5 \pm 5.8 years, and the mean disease duration was $10.6 \pm 6.5$ years. The mean steroid dose was $20 \pm 12.42 \mathrm{~g}$. AVN was monofocal in three $(34 \%)$ patients and it affected the bilateral knee or femoral head in six patients $(66 \%)$. Consistent with the literature, the femoral head was the most common $(66 \%)$ localization in our patients. Also, consistent with the results of similar studies, four of the femoral head involvements (44\%) were bilateral. Three patients $(33 \%)$ had non-femoral localization.

In this group, only one patient underwent frequent and high doses of IVMP due to very frequent attacks, and also one cure plasmapheresis was performed. Two patients received single-dose IVMP. The remaining seven patients were treated two or three times. The highest total IVMP dose was $42 \mathrm{~g}$ and the lowest total IVMP dose was $5 \mathrm{~g}$. All patients with AVN received IVMP in the last 12 months, and three patients received oral methylprednisolone therapy at different times and doses. Interestingly, no patient had a total dose of less than $5 \mathrm{~g}$. All patients had symptoms of pain. The pain was severe and did not occur with provocation, and could be confused with common pain in MS. In line with clinical suspicion, the diagnosis of all patients was confirmed by physical therapy and rehabilitation or orthopedics outpatient clinics and by magnetic resonance imaging (MRI). In our study, no statistically significant difference was found between age, duration of disease, and mean annual CS dose in patients with CDMS receiving IVMP.

\section{Discussion}

The treatment of MS can be defined as attack, DMT, and symptomatic (7). In the course of MS, attacks are an important factor in the emergence or increase of disability. Any deterioration that persists for at least 24 hours and leads to impaired patient functionality due to negative or positive symptoms may lead to a cumulative disability if not treated. For this reason, it is of great importance to treat neurologic emergencies with visual loss, motor weakness/cerebellar findings or sphincter findings $(2,9)$.

Today, IVMP stands out as the most commonly used treatment for these attacks. However, oral steroid treatment and ACTH are still used, although less commonly. IVMP is preferred as the most commonly used and prominent attack therapy because it inhibits the transcription of proinflammatory cytokines such as interleukin (IL)-1, IL-2, and tumor necrosis factor-alpha, and blocking proinflammatory enzymes such as collagenase, elastase, and plasminogen activator by integrating structures in the cell nucleus (10). In this way, migration of autoreactive T-cells and antigen expression, expression of adhesion molecules, secretion of matrix metalloproteinases, Fc expression in macrophages and major histocompatibility complex-2 expression in macrophages and microglia are suppressed (11). It is possible to limit the auto-inflammatory neurodegenerative process that can lead to irreversible damage and to start regeneration in a shorter period. The positive effect on the Extended Disability Status Scale (EDSS) was supported by studies $(12,13)$.

The most important limiting feature of steroid-containing treatments in the follow-up of MS and other idiopathic inflammatory demyelinating diseases is that they have a large and rarely disabling adverse effect profile. These most common include psychiatric symptoms, skin rashes, acute pancreatitis, gastrointestinal tract ulceration or bleeding, increased susceptibility to infection, tuberculosis exacerbation, pulmonary embolism, increased intracranial pressure, especially in children and adolescents, candidiatic esophagitis, optic nerve damage or cataract, altered glucose metabolism, increased liver enzymes, osteoporosis or bone fractures, and myopathy $(5,14)$.

The pathophysiology of AVN, which is the most common adverse effect that causes severe morbidity, is a 4-5 year-long process causing degenerative arthritis by resulting in disruption of the blood circulation of the femoral head due to the effects of mechanical and biologic factors without a significant pathology in the live elements of bone $(6,15)$. Regeneration begins with the proliferation of capillaries in the spongious bone. With the absorption of trabeculae in necrotic tissue, the newly produced live bone is made on the old tissue. The new bone formation is slower than necrotic tissue resorption, which results in bone loss, collapse, and fracture (6). In practice, the most commonly used method to confirm the diagnosis of AVN is MRI, and more rarely scintigraphy, computed tomography (CT), and single-photon

Table 2. Comparison of age, duration of disease, and annual steroid dose with chi-square analysis among all patients with multiple sclerosis receiving intravenous methylprednisolone therapy and the group with avascular bone necrosis

\begin{tabular}{llll} 
& Patient with follow-up & Patient with AVN diagnosis & p \\
Total number & $381(\mathrm{~F} / \mathrm{M}=288 / 93)$ & $9(\mathrm{~F} / \mathrm{M}=6 / 3)$ & 0.16 \\
Mean age & 28.3 & 26.5 & 0.37 \\
Mean disease duration & 9.7 & 10.5 & 0.14 \\
Mean annual steroid dose & 2.76 & 2.99 & \\
F: Female, M: Male, AVN: Avascular bone necrosis & & & \\
\hline
\end{tabular}


emission CT can be used (16). The reason why MRI examination is at the forefront in the diagnostic stage is that it also provides the possibility of staging and treatment planning (Appendix 2) $(4,6,15)$. In this retrospective study, all patients were diagnosed through MRI examination.

No direct relationship has been found in studies investigating the relationship between AVN formation and CS doses in patients with MS, but the number of patients who received lower total doses was higher in a group of patients with AVN (17). When total steroid dose, patient age, disability, and duration of disease were evaluated together, a significant difference was found in other studies (18). In other studies, osteopontin, a biomineralization factor and a cellular matrix protein that plays an important role in the inflammation process, has been mentioned (19). The relationship between osteoporosis and osteopontin concentrations has been investigated in patients with MS. The possibility of osteopontin being effective at any time during the pathogenesis of MS has been evaluated. In healthy controls, there was no relation between osteopontin and osteoporosis, but osteopontin levels were lower in patients with MS with osteoporosis. In addition, CS treatment was not associated with protein levels (20). In the autoimmune inflammatory process of MS, the disruption of osteoblast/osteoclast activities is also considered to be a condition that increases the tendency to osteoporosis $(16,20)$. One of the patients included in our study (Table 1: Patient 7) had singledosage IVMP treatment (1 g/day for 7 days) in the year of MS diagnosis, but femoral head necrosis developed in this patient. In retrospective studies conducted in the rheumatologic patient group, in which CS treatment is very common, aggressive MRI examinations are recommended for symptomatic patients becaue the highest risk period is 1-12 months after treatment $(21,22)$. In our study, all patients with AVN were found to receive IVMP in the last 12 months (22). Femoral head localization was most frequent and multifocal involvement was more frequent in accordance with the literature $(6,7)$.

\section{Study Limitations}

The retrospective nature of the study, the diagnosis of AVN in physical therapy and rehabilitation or orthopedics clinics of different centers, and some patients having their follow-ups irregularly prevented obtaining pre-diagnosis vitamin D, serum calcium, and parathormone concentrations. AVN grading could not be performed for similar reasons, and the time between the last steroid dose to the first symptoms and the time until diagnosis after symptoms could not be clearly determined. In addition, the absence of EDSS scores at the time of diagnosis of AVN is also highlighted as a limitation of the study.

\section{Conclusion}

In this retrospective study, considering the demographic characteristics and disease backgrounds of patients with AVN, patients undergoing IVMP treatment should be suspected of having AVN and diagnostic MRI should be planned in the event of severe unexplained pain symptoms that limit joint motion. Due to the autoimmune inflammatory pathogenesis of the disease, the use of IVMP, especially in patients with reduced mobility, was thought to increase the risk of $\mathrm{AVN}$ in a dose-independent manner.

\section{Ethics}

Ethics Committee Approval: The study were approved by the Bagcilar Training and Research Hospital of Clinical Research Ethics Committee (protocol number: 2018.05.1.04.047, date: 11.05.2018).

Informed Consent: Informed consent was obtained from all subjects included in our study.

Peer-review: Externally and internally peer-reviewed.

\section{Authorship Contributions}

Concept: S.Ö., Design: S.Ö., Data Collection or Processing: S.Ö., S.Y.A., Z.Y.H., S.E., Analysis or Interpretation: S.Ö., N.K., Literature Search: S.Ö., Writing: S.Ö., S.Y.A., N.K.

Conflict of Interest: No conflict of interest was declared by the authors.

Financial Disclosure: The authors declared that this study received no financial support.

\section{References}

1. Wingerchuck DM, Lucchinetti CF, Noseworthy JH. Multiple sclerosis: current pathophysiological concepts. Lab Invest 2001;81:263-281.

2. Akman Demir G. Multipl skleroz tedavisi. Klinik Gelişim 2010;1:6570 .

3. Barnes D, Hughes RA, Morris RW, et al. Randomised trial of oral and intravenous methylprednisolone in acute relapses of multiple sclerosis. Lancet 1997;349:902-906.

4. Gökçe D, Aydın Ş, Cantürk Aydın İ, Gürer R, Işık N. Multipl Sklerozda Femur Başı Avasküler Nekrozu. The Medical Bulletin of Şişli Etfal 2017;5:82-87.

5. Stanbury RM, Graham EM. Systemic Corticosteroid Therapy-Side Effects and Their Management. Br J Ophthalmol 1998;82:704-708.

6. Aaron RK, Voisinet A, Racine J, Ali Y, Feller ER. Corticosteroid-associated avascular necrosis: dose relationships and early diagnosis. Ann N Y Acad Sci 2011;1240:38-46

7. Doğan SC, Elden H, Hayta E, Güler E, Şalk İ. Pulse Steroid Tedavisi Sonrası Gelişen Multifokal Osteonekroz. Türk Fiz Tıp Rehab Derg 2014:93-94.

8. Aaron RK, Voisinet A, Racine J, Ali Y, Feller ER. Annals of the New York Academy of Sciences. 2011

9. Baygutalp F, Işı1k I, Şenel K. Multipl Sklerozlu Hastada Spastisite ile Karışabilecek Femur Başı Avasküler Nekrozu: Olgu Sunumu. Türk Osteoporoz Dergisi 2014;20:29-33.

10. Halaçoğlu F, Anlar Ö. Multipl Sklerozda Metilprednizolonun Oksidatif Strese Etkisi. KÜ Tip Fak Derg 2014;16:22-27.

11. Rosenberg GA, Dencoff JE, Correa N, Reiners M, Ford CC. Effect of steroids on CSF matrixmetalloproteinases in multiple sclerosis. Neurology 1996; $46: 1626-1632$

12. Nos C, Sastre-Carriga J, Borras C, Rio J, Tintore M, Montalban X. Clinical impact of intravenous methylprednisolone in attacks of multiple sclerosis. Mult Scler 2004;10:413-416.

13. Polman CH, Reingold SC, Banwell B, et al. Diagnostic criteria for multiple sclerosis: 2010 revisions to the McDonald criteria. Ann Neurol 2011;69:292-302.

14. Filipovic SR, Drulovic J, Stojsavljevic N, Levic Z. The Effects of high-dose intravenous methylprednisolone on event-related potentials in patients with multiple sclerosis. J Neurol Sci 1997;152:147-153.

15. Buchman A. Side Effects of Corticosteroid Therapy. J Clin Gastroenterol 2001;33:289-294.

16. Yıldız C, Koca K, Atilla HA, Ekinci Ş. Femur Başı Avasküler Nekrozunda Radyolojik Tanı. TOTBİD Derg 2013;12:62-67.

17. Kale N, Ağaoğlu J, Tanık O. Correlation of cumulative corticosteroid treatment with magnetic resonance imaging assessment of avascular femoral head necrosis in patients with multiple sclerosis. Neurol Int 2010;2:e17.

18. Zikan V. Bone Health in Patients with Multiple Sclerosis. J Osteoporosis. 2011;2011:596294. 
19. Lund SA, Giachelli CM, Scatena M. The role of osteopontine in inflammatory processes. J Cell Commun Signal 2009;3:311-322.

20. Altıntaş A, Saruhan-Direskeneli G, et al. The role of osteopontine: A shared pathway in thepathogenesis of multiple sclerosis and osteoporosis? J Neurol Sci 2009;276:41-44.

Appendix 1. Etiology of avascular necrosis of the femoral head (6)

\section{A. Traumatic}

1. Femoral neck fracture

2. Hip dislocation

3. Crush injury of the hip

4. Vascular injury

5. Hip surgery

6. Hip manipulation

\section{B. Non-traumatic}

1. Systemic steroid use

2. Excessive alcohol use

3. Use of contraceptive drugs

4. Pregnancy

5. Hyperlipidemia

6. Caisson's disease

7. Decompression sickness

8. Long stay at high altitude

9. Organ transplantation

10. Smoking

11. Radiation exposure

12. Coagulation problems and hematological diseases
a) Antithrombin 3 deficiency
b) Protein $\mathrm{C}$ and $\mathrm{S}$ deficiency
c) Plasminogen activator deficiency
d) Hemophilia
e) Polycythemia
f) Sickle cell anemia

13. Metabolic diseases
a) Hyperparathyroidism
b) Gout
c) Cushing's disease

14. Gastrointestinal system diseases
a) Pancreatitis
b) Crohn's disease
c) Ulcerative colitis

21. Özdemir H, Baloğlu M. Femur başının avasküler nekrozu: tanı ve tedavi. TOTBİD Derg 2010;9:41-51.

22. Koo KH, Kim R, Kim YS, et al. Risk Period for Developping Osteonecrosis of the Femoral Head in Patients on Steroid Treatment. Clin Rheumatol 2002;21:299-303.

Appendix 2. Radiologic staging in the avascular necrosis

of the femoral head (Ficat-Arlet classification system) (6)

\section{Stage - Criteria}

1- Normal direct radiography, magnetic resonance imaging and scintigraphy

2A- Sclerotic and cystic lesion (no subchondral cyst formation)

2B- Subchondral collapse (crescent sign) and/or subchondral stepping

3- Distortion of the contour of the femoral head

4- Joint narrowing

\section{Idiopathic}

